\title{
CHANGES IN WATER ALLOCATION MECHANISMS FOR CALIFORNIA AGRICULTURE
}

\author{
DAVID ZILBERMAN, NEAL MACDOUGALL, and FARHED SHAH*
}

\begin{abstract}
Existing institutions allocating water in Califormia reflect prior appropriation water rights established when water was abundant. These allocation rules queue users and do not encourage water conservation. Increased water scarcity and growing valuation of water's environmental benefits are inducing a transition to water allocation mechanisms that increase water efficiency in agriculture. Transferable rights systems will lead to market-like water allocation, induce farmers to adopt water conservation technology, and may not face strong objection from senior water rights holders. One must weigh the efficiency gains associated with transition from water rights to water markets against the transaction costs associated with installing facilities that enable water exchange and trading.

Transition to water markets may preserve the agricultural sector's well-being while allowing the transfer of some water outside of agriculture-in particular, for environmental benefit. The cost of policies proposed to reduce agricultural water supply while encouraging water trading are inversely related to the extent of trading allowed. The more farmers trade water, the less costly reducing water supply is to agriculture. Policies reducing water supply to Central Valley Project contractors and allowing trading only among these contractors are much more expensive than are policies encouraging trading among all agricultural water users in California.
\end{abstract}

\section{INTRODUCTION}

The increasing difficulty (and cost) of expanding water resources and increasing urban and environmental demand for water are inducing changes in California's

*The authors are, respectively, Professor, Department of Agricultural and Resource Economics, University of California, Berkeley; Graduate Student, Department of Agricultural and Resource Economics, University of California, Berkeley; Assistant Professor, Department of Agricultural and Resource Economics, University of Connecticut. This is a revised version of a paper presented at the Western Economic Association International Conference, San Francisco, Calif., July 13, 1992 in a session organized by Mark Kanazawa, Carleton College, Northfield, Minn. The authors thank Mark Kanazawa, Ron Teeples, Mason Gaffney, Linda Fernandez, and David Sunding for their useful comments. This paper is Giannini Foundation Paper No. 1072 (for reprint identification only). The study was partially supported by the EPA and BARD and a National Science Foundation Graduate Fellowship. Any opinions, findings, conclusions, or recommendations are the authors' and do not necessarily reflect the views of the National Science Foundation. water policies. Agriculture accounts for 75 percent of all water used in the state. Farmers use traditional irrigation technologies and apply much of this water to lands with relatively low-value crops, such as pasture and alfalfa. The challenge is to design viable and effective reforms that will divert water from agriculture to alternative uses. This paper explains existing patterns of California water use and evaluates the alternative reform mechanisms' potential to divert water away from agricultural to nonagricultural uses.

The paper describes California's existing water allocation mechanisms and develops a theoretical argument identifying

\footnotetext{
Abbreviations

CVP: Central Valley Project

ET: Evapotranspiration

SWP: State Water Project
} 
conditions under which transition to a market-like allocation system can improve social welfare and reduce agricultural water use without threatening agricultural viability. The potential for gains in efficiency is much larger when all agricultural water users participate in the market arrangement. Solutions advocating marketlike behavior for only some users have limited potential for economic gains.

\section{WATER ALLOCATION MECHANISMS IN CALIFORNIA}

Water allocation mechanisms determine water price and distribution to individual users. In California, a myriad of water allocation arrangements have evolved. The analysis here considers only the most prevalent arrangements pertaining to surface water. Including groundwater considerations would complicate the analysis without affecting the conclusions. The most important point is that the existing system does not yield an allocation pattern that would be achieved through a competitive market. That is to say, California's water allocation rules do not produce a market-clearing price that equates supply with demand. Instead, the rules generally are based on a "queuing" system that disallows the transfer or trading of water rights.

In California, prior appropriation and, to a lesser extent, riparian rights doctrines determine rights to water from "old" sources. These doctrines apply to most sources developed since the 19th century, except for state and federal water projects. According to Cuzon (1983), two rules characterize prior appropriation: "first come, first served" and "use it or lose it." Following the prior-appropriation queue, farmers receive water rights according to when they start diverting water. Although policy prevents users from transferring (selling) water, it does not restrict the amount of water they divert and allows them to use as much wateras they can put to beneficial use.
The riparian system in practice is another queuing system but bases allocation on location. Growers located along a river or a stream can use as much water as they need to irrigate their fields, but they cannot divert water away from the river. The riparian system initially appeared on the East Coast where the large number of rivers made diverting water far from the river banks generally unnecessary. However, in the West, the relatively smaller number of rivers necessitates diverting much water with aqueducts. The West thus adopted the prior appropriation system relying on historical rights as a guiding principle. Burness and Quirk (1979) discuss advantages of efficiency gains associated with transition from a riparian rights to a prior appropriation system for water allocation based on a variation of the prior appropriation rules. Under the Central Valley Project (CVP) and the State Water Project (SWP), recipients of this water ("contractors") receive contracts specifying the volume and price of water for a specific time period up to 40 years. Contractors cannot trade water. In principle, the pricing of project water recaptures operating and capital investment costs. In practice, CVP water has been notoriously cheap. (However, since 1987 prices have increased substantially. In 1992, Westlands Water District paid about $\$ 70$ per acre foot.) Agricultural SWP users have junior rights relative to the Southern California metropolitan district. Agricultural users and CVP water contractors have junior rights relative to exchange contractorsthat is, individuals who have prior appropriation rights for bodies of water that were dammed and diverted as part of the CVP.

Arguably, the existing water rights system in the California Central Valley effectively encouraged settlement and expansion of the state's irrigated land base. Water allocation rules-particularly in the case of the prior appropriation doctrineare comparable to homesteading in en- 
couraging settlement and land ownership. Allen (1991) demonstrates the economic rationale behind homesteading. One can use similar arguments to justify prior appropriation rights. In the early stages of land settlement, prior appropriation rights enabled farmers to obtain water for a low price. Since the price was so low, farmers did not need to establish extensive diversion facilities and could invest in inputs other than water.

Land markets replaced homesteading once the West was settled and new land became unavailable. To date, no comparable transition has occurred with regard to water resources. One reason is because California reached land constraints before water constraints, and until recently water was abundant. Additionally, differences in the nature of land and water make establishing water markets more difficult. Land is a tangible commodity characterized by its fixity. On the other hand, water's critical characteristic is its flow, which can be volatile. This characteristic makes vesting rights difficult and also complicates establishing mechanisms that produce marketlike outcomes. Furthermore, increasing returns to scale in providing and managing water conveyance systems may lead to water supply monopolies. This possibility suggests that regulated utilities or other publicly controlled organizations should ensure that water pricing is efficient and competitive.

\section{THE ECONOMICS OF TRANSITION FROM WATER RIGHTS TO WATER MARKETS}

Most California water allocation mechanisms tend to queue users, to restrict water transfer and water trading, and to charge prices that do not adequately reflect the water's scarcity value. Shah and Zilberman (1992) develop a conceptual framework for analyzing the economics of transition from queuing systems to water markets. The framework is especially applicable to the prior appropriation system. The analysis relies on Caswell and
Zilberman's (1986) and Dinar and Zilberman's (1991) irrigation choice models. These models assume that agricultural production has a constant return to scale. They concentrate on the choice of water and irrigation technology and assume that output is a function of effective water and irrigation technology. Effective water is water that the crop uses. Evapotranspiration (ET) is a common measure of consumptive water use.

Effective water is a function of applied water and can be strongly influenced by irrigation technology, especially in areas where applied water losses due to deep percolation and runoff are more likely to occur. Modern irrigation technology (for example, drip and sprinkler) can improve the uniformity of water application and thus increase the efficient delivery of water to the plant's root zone, thereby increasing the proportion of effective water to applied water. Irrigation scheduling prevents overirrigation that may occur with simple gravitational technologies such as flood or furrow irrigation. The gains associated with modern irrigation technologies increase as environmental conditions become less favorable to traditional irrigation technologies. For example, sandy soil or uneven land leads to substantial deep percolation or runoff losses.

Figures 1 and 2 present results of the Caswell-Zilberman (CZ) model. Figure 1 depicts the marginal productivity of the modern technology $\left(M P^{M}\right)$ and of the traditional technology $\left(M P^{T}\right)$. Assume that the marginal productivities are decreasing and may be negative with excessive irrigation (when applied water is greater than $a_{H}^{T}$ under the traditional technology and $a_{H}^{M}$ under the modern technology.) Assume also that the modern technology produces the same (or slightly higher) maximum output per acre than does the traditional technology and requires less water to reach its maximum yield $\left(a_{H}^{M}<a_{H}^{T}\right)$. Thus, when applied water is smaller than $a^{1}$, the 
FIGURE 1

Marginal Productivity Under Alternative Technologies

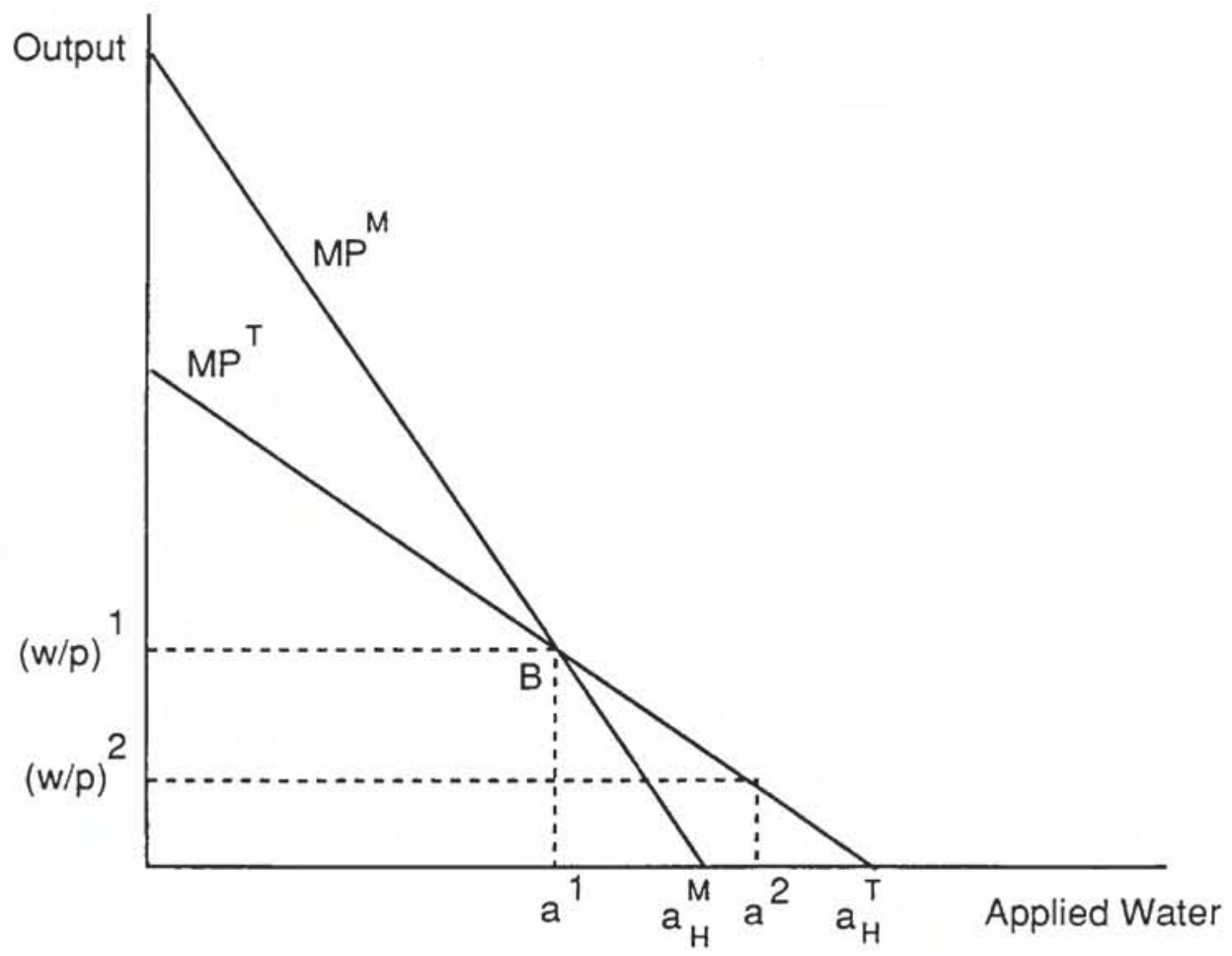

modern technology's marginal productivity is higher. However, between $a^{1}$ and $a_{H \prime}^{T}$ the traditional technology's marginal productivity is higher (the marginal product curves are linear, corresponding to quadratic production functions that seem to perform well in empirical studies of water productivity).

Figure 1 suggests that when the price of water relative to the price of output is smaller than $(w / p)^{1}$, profit-maximizing farmers use less water and realize more output using modern rather than traditional technology. When the price of water is high, modern technology may require more water but produces much more output than does the traditional technology. Under both technologies, profit is the revenues minus water costs and fixed costs.
Modern technology increases yields and is likely to save water but involves higher investment costs. Caswell and Zilberman (1986) and Dinar and Zilberman (1991) argue that modern technologies' yield-increasing and water-saving effects are likely to offset the higher investment costs as water price becomes higher. Figure 2 depicts profit per acre under both technologies as a function of water price. When water price is smaller than $w^{1}$, the traditional technology is more profitable; however, when water price is between $w^{1}$ and $w^{2}$, the modern technology is more profitable. Thus, farmers are more likely to adopt modern technologies when facing higher water prices.

Under the prior appropriation system, the farmer undertakes expense to move 


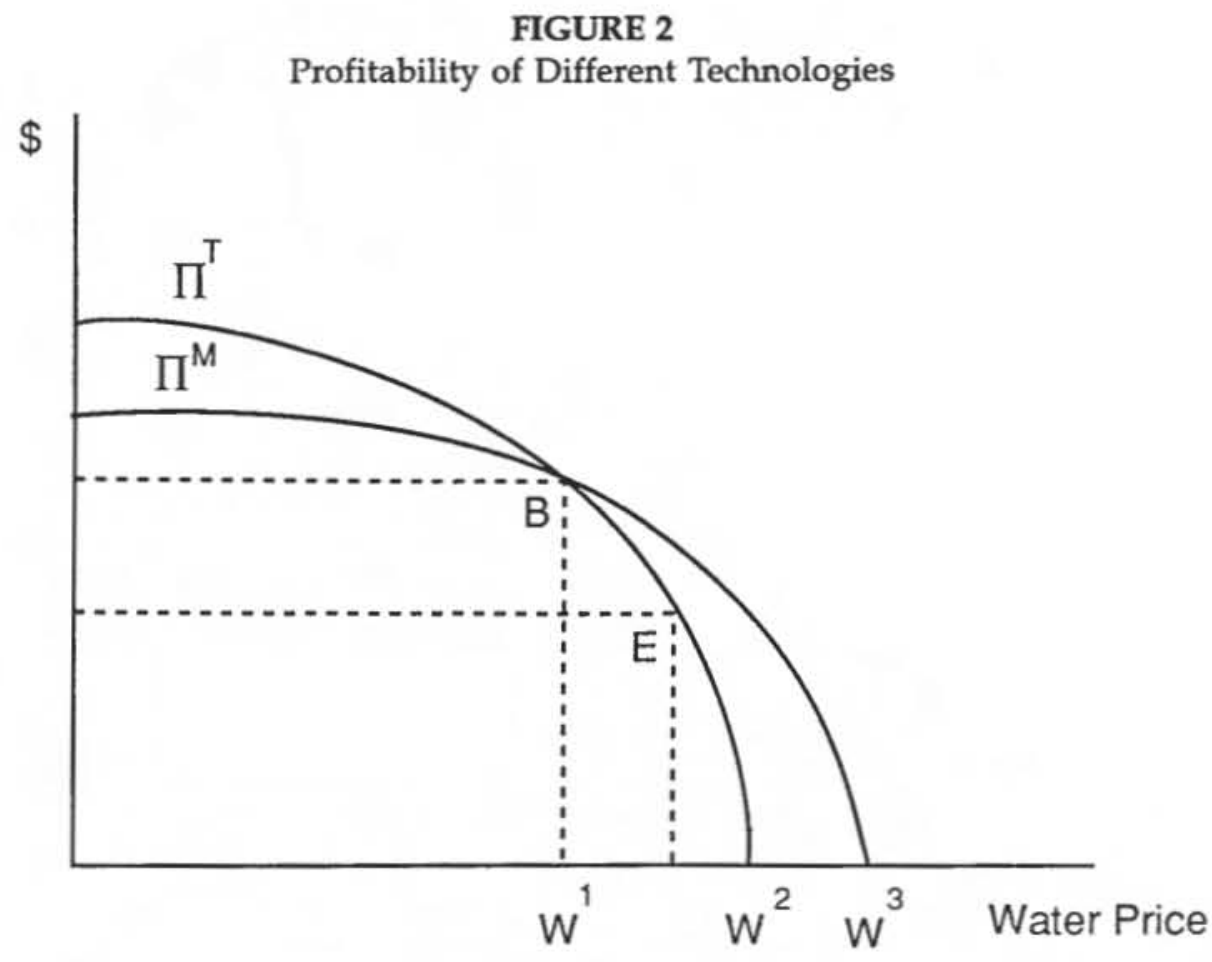

water from the canal or stream to the field but does not pay for the water's scarcity value. Thus, one assumes water's marginal price to be zero (or close to it). Therefore, profit-maximizing farmers use water at a level where the value of marginal product of applied water is zero or very close to it. Figure 2 clearly reveals that under these circumstances farmers are likely to adopt the traditional technology and use water per acre equal to $a_{\mathrm{H}}$.

Suppose that the region has a given amount of water, $A$, and the total amount of agricultural acres is $A / a F$. Under the traditional technology in the prior appropriation system, yield-maximizing water use per acre determines irrigated acreage from a given source. Water planners and irrigation experts refer to a crop's "water requirement." This level corresponds to $a F_{F}$ in figure 1 . Obviously, the higher the water requirement, the lower the acreage that a given water source can irrigate. In the past, each time the water capacity for a given source was exhausted, the government or a group of farmers exploited another water source and distributed the water among farmers according to crop water requirements. That procedure led to the water system seen in many regions, especially in the East San Joaquin Valley.

Water markets establish a water price. Farmers apply water at a level so that the value of marginal product of applied water is equal to water price. If water price is positive, then water use per acre declines relative to the prior appropriation system where water price is zero. Thus, introducing water markets should increase the amount of land that a given volume of regional water can serve. The introduction of a water market may expand irrigated land to include all farm land in the region.

If only the traditional technology is available, water use per acre under the water market is equal to A/L (total water/available land) and water price cor- 
responds to point $\mathrm{E}$ in figure 2 (assuming that the price at $\mathrm{E}$ is the value of marginal product when water per acre is $A / L$ ). When more than one technology is available, different outcomes are possible. First, if the ratio $A / L$ is relatively large and the resulting water price is smaller than $w^{1}$ in figure 2, then all farmers use the traditional technology. Alternatively, when water is scarce and $A / L$ is relatively small so that water price is greater than $w^{2}$ in figure 2, all farmers use the modern technology. A third possible outcome results when water price is between $w^{1}$ and $w^{2}$ in figure 2. In this case, some farmers adopt the modern technology, and others adopt the traditional technology. The marginal physical product of applied water is identical in both firms and is equal to $(w / p)^{2}$ in figure 1. However, the traditional technology requires more water than does the modern technology. Obviously, using both technologies makes the quasi rent per acre (the difference between the revenue and water cost) equal under both technologies.

Farmers use only the traditional technology under the market when the water per acre ratio is relatively high and water use per acre is relatively close to $a$ f . The efficiency gain associated with moving from water rights to a market system results from being able to cultivate more land with a given amount of water. That is, moving water that has a relatively low marginal productivity on the land used under the prior appropriation system to land that has not be utilized before increases water productivity on this new land. (Alternatively, some excess water can be moved from agriculture and used in other activities having high marginal productivities). Adopting modern technology enhances water productivity of water even further but entails higher investment costs. If extra acreage beyond what was settled under the prior appropriation system is minimal, the productivity gain associated with adopting the modern technology may be so insignifi- cant that adoption is unlikely. If the water per acre ratio is relatively small, farmers likely will apply the modern technology on all land. In this case, the water price is relatively high, a large increase in output occurs, and water use per acre drastically declines. A middle solution may occur when a water market increases the land base but the productivity gain is not sufficient to justify completely adopting the modern technology. In this case, farmers use the modern technology on some land and the traditional technology on other land consistent with market-clearing rules.

The analysis here suggests that transition from a water rights regime to a water market increases economic efficiency. This is true if the transition from one system to another does not entail adjustment costs. However, the prior appropriation system and the zero scarcity value of water it entails permit establishing a very inexpensive water conveyance system requiring little monitoring, especially if all land belongs to farmers who have water rights. Transition to a water market may require expanding conveyance systems, improving measuring and metering, and increasing monitoring and protection of water flows. If the efficiency gain from operating the new system is smaller than the adjustment costs of the transition, then the transition is not totally efficient. Indeed, lack of demand, low commodity prices, or a high initial water to land ratio may mean the amount of land that farmers optimally can utilize under a market is not much bigger than the amount they utilized under the prior appropriation system. In this case, the prior appropriation system is more efficient than a market, given transition costs. That may be why the system was established in the first place. Over time, as demand for commodities produced with water increases and their prices rise, or as adjustment costs improve due to better technology, water markets are likely to become more efficient, and one can justify transition. 
With transition to a water market, the farmer who had a right to water under prior appropriation now must purchase it, perhaps from a government agency. Obviously, the farmer loses therefore likely opposes the transition. Ameliorating the situation may involve introducing "transferable rights," which allow farmers with senior rights to sell excess water to farmers whose land is not included under the prior appropriation system. Farmers with prior appropriation rights now benefit from the transition and are less likely to oppose it. Of course, exceptions exist. For example, if the elasticity of demand for the commodities produced by farmers is low, senior rights owners may object that the transition would expand production, reduce output prices, and reduce their income. Realistically, that probably is not the case. Such objections seem unlikely if adjustment costs associated with transition to a market system are sufficiently low and farmers enjoying senior rights under the existing regime are confident that they will be able to retain these rights, transfer water, and gain income. The California Farm Bureau is not opposed to introducing institutions like transferable rights.

Shah and Zilberman (1992) base their numerical example on parameters from the California cotton industry and assume that relatively light soils and uneven land characterize the geography. Table 1 shows some of their results along with parameter values. Four irrigation technologies are available: furrow, shortened runs, sprinkler, and drip. The first two may be relatively inefficient-especially at locations with sandy soils and uneven land-and are traditional technologies. The latter two are modern technologies having higher irrigation efficiency and higher set-up and other fixed costs (table 1).

The example uses a hypothetical case of a region with 3 million acre feet (MAF) of water. Computer simulations obtain input use and output allocations for both prior appropriation and market mechanisms.
Under the prior appropriation system, only 720,000 acres are utilized when output price is $\$ 0.75 / \mathrm{lb}$. This price and the corresponding queuing output serve as benchmark values around which demand elasticity varies from 1 to 50 . If the adjustment costs are relatively low (\$5.00/AF) and demand for cotton is elastic, transition to a water market permits utilizing the land in all cases, even when 1,100,000 acres are available. However, as the water/land ratio becomes smaller, the dominant technology in the region becomes more advanced. For instance, when the region has 1,050,000 acres of land and the demand elasticity for cotton is 50 , farmers use sprinkler irrigation throughout the region. In this case, transition increases the irrigated land base by about 46 percent and social welfare by about 24 percent.

Demand elasticity is an important element in this analysis. The higher the elasticity, the greater the likelihood that farmers utilize the more advanced technologies for a given amount of land, and the greater the benefit from transition to a water market system. Shah and Zilberman also show that even though adjustment costs are important from a conceptual standpoint, the level of costs that would make a transition to a water market system inefficient is substantial.

Shah and Zilberman elaborate on the case with zero adjustment costs. In the hypothetical example, if water availability to the region declines by 25 percent and a transition occurs from water rights to a water market, the farmers' well-being under the water market is the same as under the prior appropriation system. Thus, great potential exists for transferring nonagricultural water without reducing farmers' well-being if the transfer also involves transition to a water market. Obviously, the higher the transition's adjustment costs, the less water is available for transfer away from agriculture. 
TABLE 1

\begin{tabular}{|c|c|c|c|c|}
\hline Technology & \multicolumn{2}{|c|}{ Irrigation Efficiency } & Fixed Cost & \\
\hline Furrow (1) & \multicolumn{2}{|l|}{0.6} & 500 & \\
\hline Shortened-Run (2) & \multicolumn{2}{|l|}{0.7} & 517 & \\
\hline Sprinkler (3) & \multicolumn{2}{|l|}{0.8} & 548 & \\
\hline Drip (4) & \multicolumn{2}{|c|}{0.95} & \multicolumn{2}{|l|}{633} \\
\hline $\begin{array}{l}\text { Land Base }\left(10^{3} \text { acres }\right) \\
\text { Demand Elasticity }\end{array}$ & $\begin{array}{r}900 \\
1\end{array}$ & $\begin{array}{r}900 \\
50\end{array}$ & $\begin{array}{r}1050 \\
1\end{array}$ & $\begin{array}{r}1050 \\
50\end{array}$ \\
\hline \multicolumn{5}{|c|}{ Queuing Outcomes } \\
\hline Output $\left(10^{6} \mathrm{lbs}.\right)$ & 936 & 936 & 936 & 936 \\
\hline Output Price $(\$ / \mathrm{lb})$. & 0.75 & 0.75 & 0.75 & 0.75 \\
\hline Irrigated Land ( $10^{3}$ acres) & 720 & 720 & 720 & 720 \\
\hline \multicolumn{5}{|c|}{$\begin{array}{c}\text { Market Outcomes } \\
\text { Adjustment Costs }=\$ 5 / a c r e\end{array}$} \\
\hline Output ( $\left.10^{6} \mathrm{lbs}.\right)$ & 1159 & 1161 & 1161 & 1344 \\
\hline Output Price $(\$ / \mathrm{lb}$.) & 0.572 & 0.746 & 0.57 & 0.744 \\
\hline Water Price (\$/AF) & 62.0 & 73.75 & 63.7 & 118.4 \\
\hline Irrigated Land ( $10^{3}$ acres) & 900 & 900 & 902 & 1050 \\
\hline Technologies & 2 & 2,3 & 2 & 3 \\
\hline Percent Gain in Social Welfare & $5.4 \%$ & $16.3 \%$ & $5.4 \%$ & $23.8 \%$ \\
\hline
\end{tabular}

Shah and Zilberman abstract from many issues. They consider only three technological alternatives to traditional irrigation-short run, sprinkler, and dripignoring the great potential for water savings and yield increases associated with, for example, irrigation scheduling. They do not consider crop substitution as a response to a high water price. A transition away from water-consuming crops to other crops that bring higher profits per acre foot of water also deserves consideration. Nevertheless, Shah and Zilberman establish the potential gain from moving to a market system that overcomes the inefficiency of a prior appropriation system. Moreover, for 25 percent of the irrigators who use surface water, the allocation does not exactly follow the prior appropriation system. Those irrigators receive water from the state and federal water projects and are, in effect, water project contractors. 


\section{WATER CONTRACTING}

Water contractors, like prior appropriators, cannot trade their water, but periodically can renegotiate their contracts. In principle, contract prices were designed to repay project costs. While SWP prices are high (sometimes reaching $\$ 80$ per acre foot), historically the CVP water has been cheap and highly subsidized. Some who receive water from the federal water project have been unable to receive all the water they want at the subsidized prices. Moore et al. (1992) document that the shadow price of water used by the contractors, at least in the late 1980 s, was much higher than the price paid. Thus, federal and state water project contractors' behavior reflects the positive price of water. Therefore, their water application per acre is lower and their water efficiency is higher than are those of the prior appropriators who, in many cases, experienced water prices close to zero.

Furthermore, water contractors' rights are junior to the prior appropriators' rights. Therefore, the contractors are further down the queue. Whenever a severe drought or water shortage occurs, the contractors' supplies are more likely to be cut than are those of many farmers who are prior appropriators. For example, the 1990-1991 drought did not affect the supply of water to many prior appropriators while many contractors received between 25 to 50 percent of their usual water allotment.

Much evidence suggests that water project contractors use water more efficiently than do prior appropriators. For example, the State Water Resources Control Board shows that in 1989, CVP-contracting cotton growers in the Westlands Water District used about 20 percent less water and gained about 20 percent more output than did the Valley growers who likely are prior appropriators. MacDougall et al. (1992) find that farmers in the Broadview Water District use 20 percent less water for the same yields as do nearby farmers in the Central California
Irrigation District. Differences in land quality or other farming conditions in the two regions are small. Therefore, higher water price led to the water savings. Furthermore, some of the water districts like Broadview have introduced tiered pricing to encourage farmers to adopt modern irrigation technologies and conserve water. Indeed, the first farmers to use drip irrigation in cotton production were state or federal project contractors. Similarly, water-project water recipients are more likely to adopt irrigation scheduling and other water-saving managerial practices.

Patterns of water transactions depend upon the participants in the water market. If trading is limited to agriculture, contractors will purchase water from prior appropriators. If the market includes urban sectors, prior appropriators will be sellers, cities will be buyers, and contractors may be either buyers or sellers. If the environment is an autonomous player in the market with the capacity to purchase water, it also will be a water buyer. Understanding transaction patterns is especially important for analyzing the impact of new water quality regulations in California.

\section{WATER MARKETS THAT REDUCE COSTS OF MEETING WATER QUALITY GOALS}

Concern for water quality in the San Francisco Bay and Delta is leading state and federal agencies to consider new water quality standards requiring diversion of more water to environmental uses. Because environmental quality is a public good in the economic sense, the "free rider" problem is likely to cause underprovision of private funds to purchase water for environmental purposes. Therefore, government intervention is needed. Current fiscal constraints prevent the government from allocating funds to purchase water for environmental uses. Instead, the government has considered and enacted policies to divert some of the governmentsupplied water to environmental use. Government agencies also considered es- 
tablishing new water quality standards requiring more water diversion from agricultural to environmental uses.

The recently enacted Central Valley Improvement Act (Bradley-Miller Bill) mandates reallocating $800,000 \mathrm{AF}$ of CVP water from agricultural contractors so as to improve San Francisco Bay and Delta water quality. Allowing water transfer between the CVP contractors (and thus establishing a water market) complements this reallocation.

The act has the ingredients of a desirable reform. The efficiency gain associated with introducing markets will save some of the cost as with water supply reduction. This and similar proposals such as the defeated Johnston Bill calling for transfer of 2.5 MAF from the contractors to environmental uses are relatively easy to implement because state and federal governments supply the water to contractors. However, such proposals have limited potential for improving welfare. Contractors are likely to use water more efficiently than do prior appropriators. Contractors consume less than 30 percent of California surface water. Therefore, efficiency gains from introducing a water market solely among contractors are limited. If water is to be taken away from contractors, efficient reform must establish a water market that includes all agricultural users-contractors and prior appropriators. Indeed, policies that significantly reduce water supplied to contractors will be very costly outside an agricultural water market.

Zilberman et al. (1993) use several approaches to estimate impacts on agricultural income of reassigning water from CVP contractors to environmental uses while allowing water trading between contractors. (Measuring impacts on economic surplus may be more appropriate, but policymakers are interested in impacts on revenue and employment growth.) To find the upper bound on short term impacts, Zilberman et al. consider that the response to water supply reduction will be fallowing of land used with low-value crops. Figures 3, 4, and 5 depict revenues per acre foot as a function of the cumulative volume of water applied in three regions receiving water from the Central Valley Project. The Westlands Water District and the Friant-Kern region are south of the Delta, and the Tehama-Colusa is north of the Delta. The figures show great variability in revenues associated with water used on different crops in different regions. Water used with high-value tree crops generates more than $\$ 1,000$ per acre foot, but water used with low-value crops such as pasture and alfalfa generates very low revenues. Regions south of the Delta regions tend to generate, higher revenues per acre than does Tehama-Colusa, whose return structure resembles those of many prior appropriators located in the northeast Central Valley.

The income reductions associated with reducing supply to CVP contractors is likely to be different if the reductions apply to all contractors or only to contractors south of the Delta. If the reform affects all contractors and allows trading between them, the 0.8 MAF reduction that the Bradley-Miller Bill calls for mostly will reduce acreage devoted to hay, irrigated pasture, and rice, crops which generate less than $\$ 100 / \mathrm{AF}$. Restricting reductions to growers in Westlands and other nearby districts will reduce the cotton acreage that generates more than $\$ 250 / \mathrm{AF}$ in revenues. Similarly, reducing 2.5 million AF of water among all Bureau contractors will reduce the fallowing of rice, sorghum, wheat, and hay acreage and some fallowing of cotton. If the reduction applies only to contractors south of the Delta, most of the land for cotton will be fallowed as well as some land for almonds. Thus, extending the range of producers that the water supply reduction affects drastically reduces the economic implications.

Zilberman et al. (1993) estimate that reducing the water supply to CVP contractors by $0.8 \mathrm{MAF}$ as suggested by the Brad- 
FIGURE 3

Friant Unit Earnings per AF of Applied Water and Cumulative

Water Usage (AF), by Crop for 1990

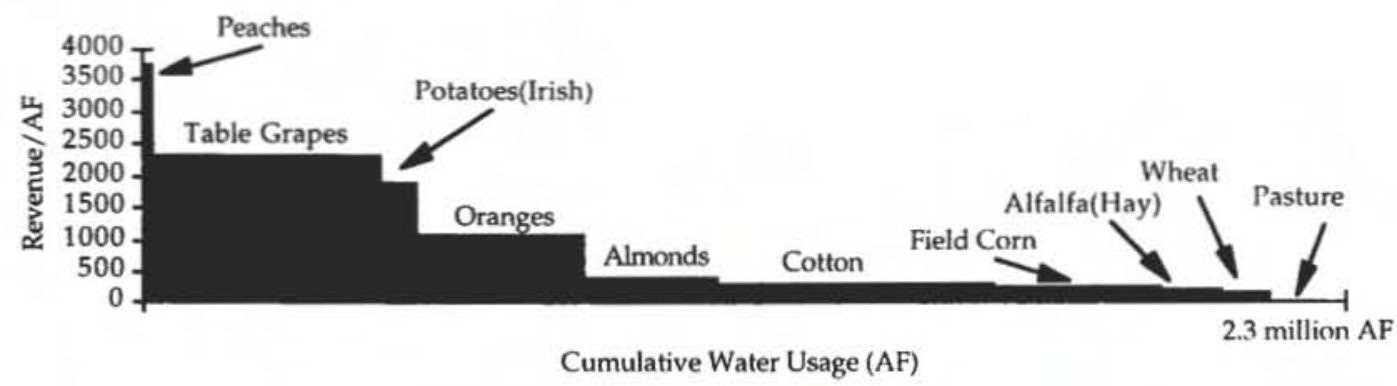

FIGURE 4

Westlands Water District Earnings per AF of Applied Water and Cumulative Water Usage (AF), by Crop for 1990

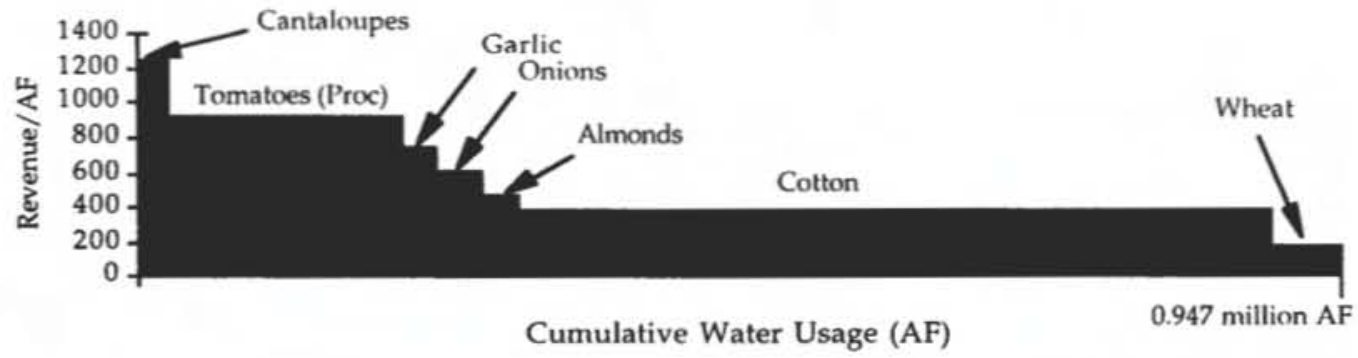

FIGURE 5

Tehama-Colusa Earnings per AF of Applied Water and Cumulative Water Usage (AF), by Crop for 1990

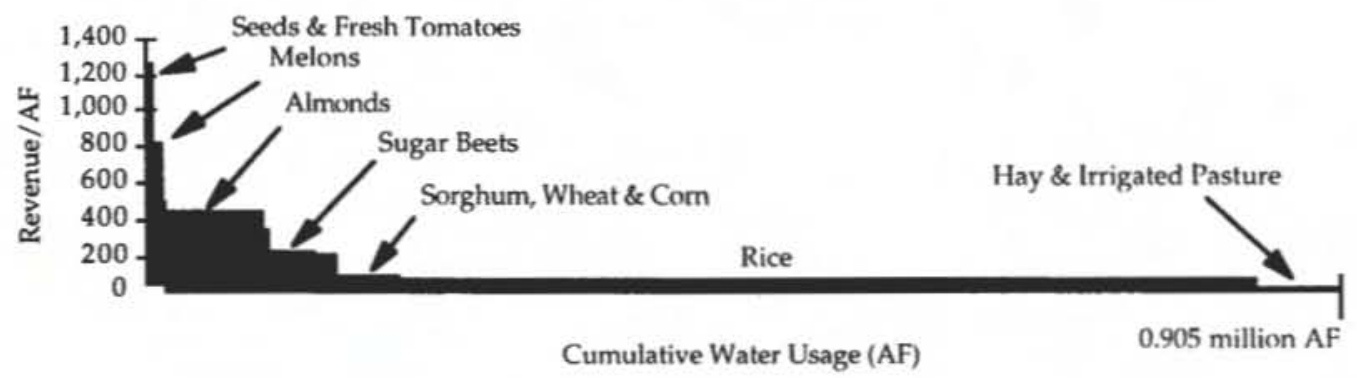


ley-Miller Bill will reduce their revenues by $\$ 50-\$ 120$ and will lose 2,000 to 4,000 man-years of employment annually. Furthermore, reducing 2.5 MAF in agricultural water supply to CVP water contractors would lead to an estimated annual revenue loss of between $\$ 400$ million and $\$ 780$ million and a loss of between 10,000 to 19,000 man-years of work. The impacts would be much less significant if the water transfer occurs in conjunction with the introduction and encouragement of water transfers between regions and with the development of new conveyance facilities to ensure efficient water use across the state.

Actually, transferring a substantial amount of water from agriculture to the environment in California, introducing transferrable rights, and creating an agricultural water market may cause contractors to buy water and prior appropriators to adopt improved irrigation technologies and use less water more efficiently. California agriculture uses about 20 MAF of surface water annually. The analysis here suggests that transferring 10 percent of this water from agriculture and introducing a water market (that is, allowing transferrable water rights) may not leave California farmers worse off. Of course, such reform is complex and must address other issues, including managing groundwater and third-party effects as well as developing compensation mechanisms to ensure that none of the major parties in the state are big losers and that transition impacts are equitably divided.

\section{REFERENCES}

Allen, D., "Homesteading and Property Rights: or, 'How the West Was Really Won,'" Journal of Law and Economics, Vol. 34, 1991, 1-23.

Burness, H. S., and J. Quirk, "Appropriative Water Rights and Efficient Allocation of Resources," American Economic Review, Vol. 69, 1979, 25-37.

Caswell, Margriet, and David Zilberman, "The Effects of Well Depth and Land Quality on the Choice of Irrigation Technology," American Journal of Agricultural Economics, Vol. 68, 1986, 798-811.

Cuzan, A., "Appropriators Versus Expropriators: The Political Economy of Water in the West," in T. Anderson, ed., Water Rights: Scarce Allocation, Bureaucracy, and the Environment, Ballinger Publishing Company, Cambridge, Mass., 1983.

Dinar, Ariel, and David Zilberman, "Effects of Input Quality and Environmental Conditions on Selection of Irrigation Technologies," in A. Dinar and D. Zilberman, eds., The Economics and Management of Water and Drainage in Agriculture, Kluwer Academic Publishers, Norwell, Mass., 1991.

MacDougall, Neal, W. Michael Hanemann, and David Zilberman, "The Economics of Agricultural Drainage," report to the Central Valley Regional Water Quality Control Board, Standard Agreement No. 0-132-150-0, Department of Agricultural and Resource Economics, University of California, Berkeley, August 1992.

Moore, Michael, Marc B. Carey, and Noel R. Gollehon, "Multicrop Decisions in Western Irrigated Agriculture: Econometric Analysis and Producer's Surplus Measurement," Resources and Technology Division, Economic Research Service, USDA, Draft, April 30, 1992.

Shah, Farhed, and David Zilberman, "Queuing vs. Markets," Department of Agricultural and Resource Economics, University of California, Berkeley, 1992.

Solomon, Kenneth H., Dennis Nef, Greg Jorgensen, and David Zoldoske, "Higher Agricultural Electricity Rates: A San Joaquin Valley Perspective," study developed for the California Energy Commission, Center for Irrigation Technology, School of Agricultural Science and Technology, California State University, Fresno, March 18, 1992.

State Water Resources Control Board, Report by the Bay/Delta Agricultural Water Conservation SubWork Group No. 1; and the Westlands' "Water Conservation and Drainage Reduction Programs 1987-1988."

Zilberman, David, Richard E. Howitt, David Sunding, Linda Fernandez, and Neal MacDougall, "The Economic Impacts of Water Quality Regulations in the San Francisco Bay and Delta," report to the Environmental Protection Agency, San Francisco, Calif., March 1993. 